\title{
ANALISIS SEBAB AKIBAT PADA PENGELOLAAN KUALITAS SUSU SEGAR DI KABUPATEN JEMBER, JAWA TIMUR (Studi Kasus pada Produksi Susu Segar di KPGM Kabupaten Jember)
}

\author{
Uyun Erma Malika $^{* 1}$, Jemi Cahya Adiwijaya ${ }^{* 2}$ \\ ${ }^{*} 1,2$ Jurusan Manajemen Agribisnis, Politeknik Negeri Jember \\ Jl. Mastrip PO BOX 164 Jember - Jawa Timur \\ ${ }^{1}$ uyun.polije@gmail.com \\ 2jemiadiwijaya356@gmail.com
}

\begin{abstract}
Abstrak
Susu segar merupakan salah satu komoditas peternakan yang diperoleh dari budidaya sapi perah. Susu segar yang berkualitas sangat diharapkan oleh para peternak pada saat proses pemerahan, berkaitan dengan permintaan konsumen khususnya Industri Pengolahan Susu (IPS) yang mensyaratkan kualitas susu segar. Tujuan dari penelitian ini adalah untuk mengidentifikasi faktor-faktor yang mempengaruhi manajemen kualitas produksi susu segar, dengan melakukan studi kasus di Koperasi Peternak Galur Murni (KPGM) Kabupaten Jember. Penelitian ini merupakan jenis penelitian case study (studi kasus) guna mempelajari secara intensif atau mendalam dari kelompok sasaran penelitian. Metode analisis yang digunakan berupa analisis cause and effect diagram untuk mengidentifikasi faktor-faktor yang mempengaruhi manajemen kualitas produksi susu segar di KPGM. Berdasarkan hasil penelitian menunjukkan bahwa faktor-faktor yang berpengaruh dalam kualitas susu segar di KPGM yaitu berupa lemahnya pengawasan peternak, ketersediaan jumlah pakan hijauan, sistem pemerahan yang tidak terpisah dengan kandang (minimnya infrastruktur), peralatan yang digunakan masih sederhana, dan ketersediaan air. Rencana penanggulangan yang dapat dilakukan yaitu berupa control kualitas di setiap segmen, perbaikan pengelolaan pakan hijauan, pembangunan infrastruktur, penyuluhan dan pengadaan peralatan, dan pembuatan sumber mata air artesis.
\end{abstract}

Kata kunci: Susu segar, cause and effect diagram, kualitas

\section{PENDAHULUAN}

Peningkatan kualitas produk merupakan hal terpenting dalam pemasaran, salah satunya yaitu produk susu segar yang diperoleh dari pemerahan sapi perah. Menurut Kotler (2000:748) kualitas produk adalah keistimewaan, yakni karakteristik yang melengkapi fungsi suatu produk dapat berupa bentuk modal atau struktur fisik suatu produk yang lebih baik dibandingkan dengan produk lain yang sejenis. Kualitas produk yang dimaksudkan dalam penelitian ini difokuskan pada sisi konsumen. Hal ini sesuai dengan definisi kualitas menurut Gaspersz (2008), kualitas adalah segala sesuatu yang mampu memenuhi keinginan atau kebutuhan pelanggan (meeting the needs of customers).

217 | Analisis Sebab Akibat Pada Pengelolaan Kualitas Susu Segar Di Kabupaten Jember, Jawa Timur (Studi Kasus pada Produksi Susu Segar di KPGM Kabupaten Jember) 
Bahkan kualitas sering sering dianggap sebagai parameter kepuasan pelanggan (customer satisfaction). Kualitas yang mengacu pada kepuasan pelanggan nantinya dapat digunakan sebagai upaya perubahan ke arah perbaikan terus-menerus bahkan sebagai upaya penguatan daya tawarnya (bargaining position).

Koperasi Peternak Galur Murni (KPGM) merupakan salah satu koperasi penghasil susu segar dan produk olahan susu yang berlokasi di Kabupaten Jember dengan nama produknya adalah "Best Cow". Koperasi ini dijadikan sebagai wadah bagi beberapa peternak sapi perah di Kabupaten Jember, untuk belajar dan mengembangkan usahanya. Berdasarkan Jawa Pos Radar Jember 19 Juli 2016 jumlah anggota koperasi yang sudah bergabung sekitar 47 peternak sapi sejumlah 275 ekor.

Para peternak sapi perah cenderung mengabaikan kualitas susu segar yang dihasilkan, baik waktu pemerahan maupun proses pasca panen. Padahal banyak konsumen yang sudah mengetahui kualitas susu segar ataupun produk olahan susu yang baik. Menurut Sri Usmiati dan Abubakar (2009:13) rendahnya kualitas susu yang dihasilkan oleh peternakan rakyat diantaranya merupakan akibat sistem manajemen pemerahan dan penanganan susu yang belum sesuai standar sehingga berimbas pada susu peternak yang dihargai relatif murah oleh Industri Pengolahan Susu (IPS) dengan penetapan standar kualitas susu yang semakin ketat. Jadi apabila susu segar tersebut tidak masuk dalam kriteria kualitas IPS maka susu segar tersebut akan ditolak masuk IPS atau akan diberikan harga yang cenderung sangat murah, sehingga hal ini dapat merugikan para peternak.

Adapun tujuan penelitian dari penelitian adalah untuk mengidentifikasi faktorfaktor yang mempengaruhi manajemen kualitas produksi susu segar, khususnya pada Koperasi Peternak Galur Murni (KPGM) Kabupaten Jember.

218 | Analisis Sebab Akibat Pada Pengelolaan Kualitas Susu Segar Di Kabupaten Jember, Jawa Timur (Studi Kasus pada Produksi Susu Segar di KPGM Kabupaten Jember) 


\section{METODE PENELITIAN}

Tahapan Penelitian

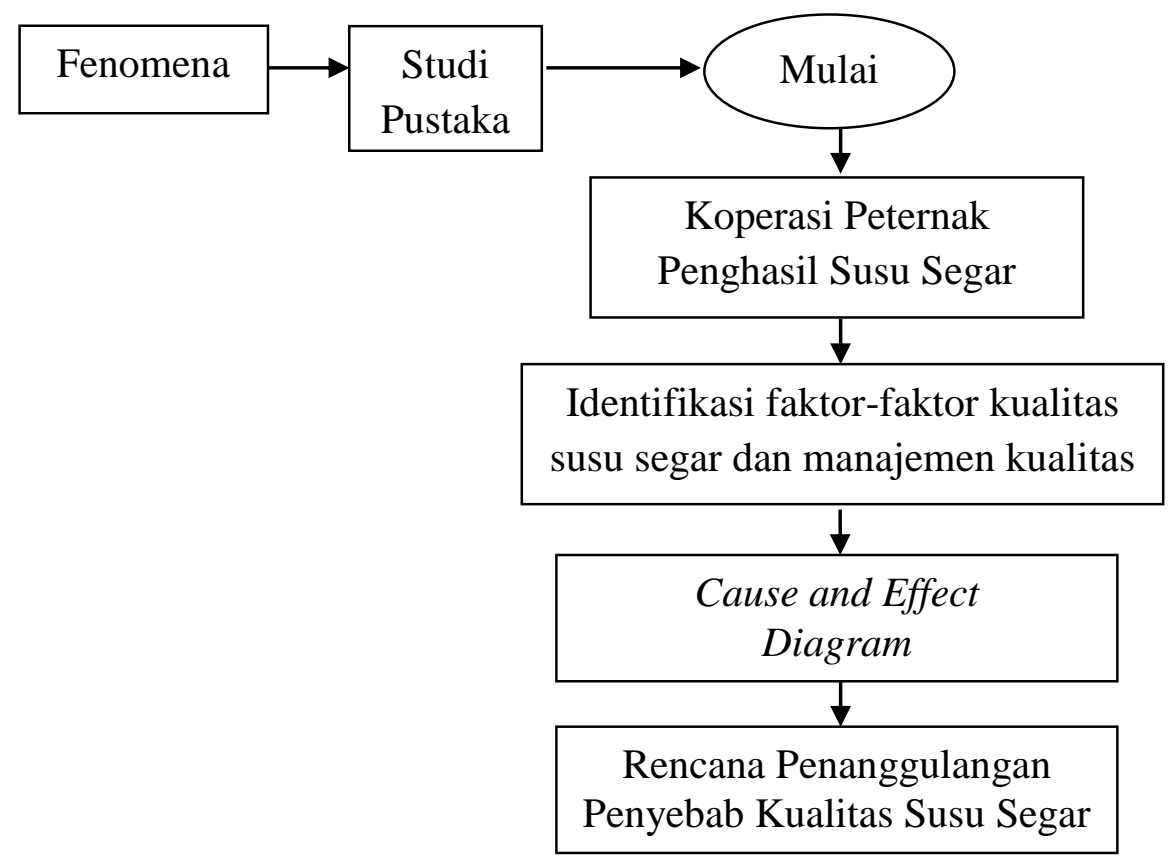

\section{Gambar 1. Tahapan-Tahapan Penelitian}

\section{Rancangan Penelitian}

Desain penelitian yang digunakan adalah studi kasus (case study). Menurut Silalahi (2010:186) penelitian kasus atau studi kasus merupakan penelitian yang mempelajari secara intensif atau mendalam satu anggota dari kelompok sasaran subjek penelitian. Dalam penelitian ini yang dijadikan sebagai subjek penelitian adalah mutu produk susu segar pada Koperasi Peternak Galur Murni (KPGM). Identifikasi faktorfaktor yang mempengaruhi manajemen kualitas produksi susu segar menggunakan cause and effect diagram.

\section{Teknik Pengambilan Sampel}

Teknik pengambilan sampel dalam penelitian ini menggunakan purposive sampling. Menurut Silalahi (2010:272) pemilihan sampel purposive atau bertujuan, terkadang disebut sebagai judgment sampling, merupakan pemilihan siapa subjek yang ada dalam posisi terbaik untuk memberikan informasi yang dibutuhkan. Dalam penelitian ini yang ditunjuk sebagai sumber informan terpilih adalah Koperasi Peternak Galur Murni. 


\section{Instrumen Penelitian}

Instrumen yang digunakan dalam penelitian ini adalah menggunakan kuesioner terbuka dan wawancara guna memperoleh data Cause and Effect Diagram.

\section{Analisis Data}

Cause and Effect Diagram adalah suatu diagram yang menunjukkan hubungan diantara sebab dan akibat. Pada dasarnya diagram sebab akibat dapat dipergunakan untuk membantu mengidentifikasi akar penyebab dari suatu masalah, membangkitkan ide-ide untuk solusi suatu masalah, dan menyelidiki fakta lebih lanjut. Adapun langkah-langkah dalam pembuatan Cause and Effect Diagram menurut Vincent Gasperz (2012) dikemukakan sebagai berikut:

a. Mulai dengan pernyataan masalah-masalah utama yang penting dan mendesak untuk diselesaikan.

b. Tuliskan pernyataan masalah tersebut dan gambar sebagai "kepala ikan" yang merupakan akibat (effect), kemudian gambarkan "tulang belakang” dari kiri ke kanan dan tempatkan pernyataan masalah dalam kotak.

c. Tuliskan factor-faktor penyebab utama (cause) yang mempengaruhi masalah kualitas sebagai "tulang besar" (juga tempatkan dalam kotak). Faktor penyebab dapat dikembangkan melalui stratifikasi pengelompokan dari faktor-faktor manusia, mesin, peralatan, material, metode kerja, lingkungan kerja, dan lain-lain.

d. Tuliskan penyebab sekunder yang mempengaruhi penyebab utama dan nyatakan sebagai "tulang-tulang berukuran kecil".

e. Tentukan item-item yang penting dari setiap faktor dan tandai faktor-faktor penting tertentu yang kelihatannya memiliki pengaruh nyata terhadap karakteristik kualitas.

f. Catat informasi yang perlu di dalam Cause and Effect Diagram tersebut seperti judul, nama produk, proses, kelompok, daftar partisipan tanggal, dan sebagainya.

\section{HASIL DAN PEMBAHASAN}

Koperasi Peternak Galur Murni (KPGM) merupakan salah satu koperasi yang terdapat di Kabupaten Jember. KPGM berlokasi di Dusun Sadengan, Desa Rowotengah, Kecamatan Sumberbaru, Kabupaten Jember, Provinsi Jawa Timur (seperti tampak pada gambar 5.1). Adapun bidang fokus koperasi ini adalah bergerak di bidang peternakan 
khususnya sapi perah. Koperasi Peternak Galur Murni pada awalnya sudah mulai dibentuk sejak tahun 1999 dan mulai bergerak pada bidang peternakan sapi perah sejak tahun 2010 hingga saat ini dengan SIUP Nomor 503/513/436.314/2006 dan TDP (Tanda Daftar Perusahaan) 13.07.2.52.00522.

Koperasi Peternak Galur Murni (KPGM) ini mengelola beberapa unit kegiatan usaha selain kegiatan simpan pinjam seperti koperasi yang ada pada umumnya. Unit kegiatan usaha yang dikelola koperasi tersebut menghasilkan produk-produk seperti susu segar, susu pasteurisasi, yoghurt. Koperasi ini mewadahi para anggotanya dalam mendistribusikan susu segar yang dihasilkan oleh sapi perah para peternak anggota KPGM. Susu segar tersebut biasanya ditampung atau dikumpulkan kemudian disetor ke Industri Pengolahan Susu (IPS). Upaya mempermudah pengepulan susu segar dari para peternak anggota KPGM yang tersebar di beberapa wilayah di Kabupaten Jember, maka lokasi pengepulan terbagi di tiga titik wilayah yaitu di Kecamatan Ajung, Kecamatan Balung, dan Kecamatan Sumberbaru. Ketiga unit pengepulan susu segar tersebut dapat dilihat pada gambar 5.1 berikut ini.

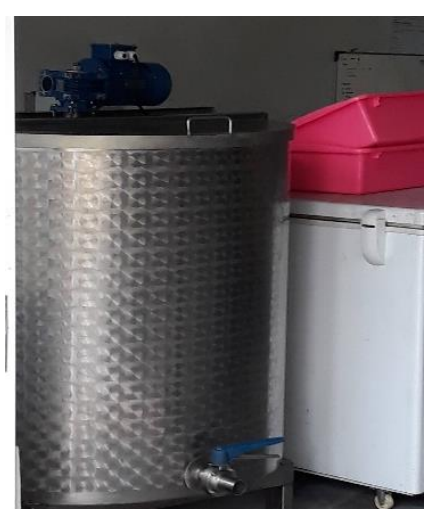

Unit Ajung

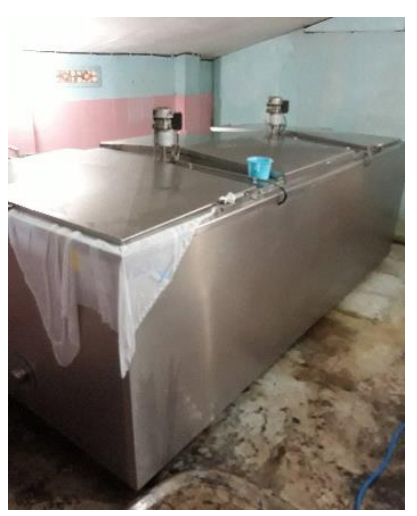

Unit Balung

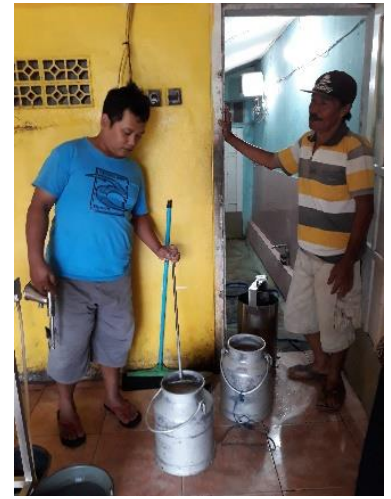

Unit Sumberbaru

Gambar 1. Unit-unit Lokasi Pengepulan Susu Segar KPGM

Masing-masing tempat pengepulan susu segar tersebut melakukan kegiatan penerimaan susu segar dari para peternak yang tergabung dalam KPGM pada waktu pagi dan sore hari. Masing-masing tempat pengepulan tersebut dilengkapi dengan cooling box yang berguna sebagai tempat penampungan sementara susu segar dari para peternak. Setelah proses pengepulan di ketiga unit wilayah tersebut, kemudian susu segar dikirim ke industri yang sudah bermitra dengan KPGM. Dalam hal ini, KPGM bekerjasama atau bermitra dengan suatu industri pengolahan susu yaitu Nestle.

221 | Analisis Sebab Akibat Pada Pengelolaan Kualitas Susu Segar Di Kabupaten Jember, Jawa Timur (Studi Kasus pada Produksi Susu Segar di KPGM Kabupaten Jember) 
Berdasarkan hasil wawancara mendalam (indepth interview) yang telah dilakukan dengan pihak responden yang terdiri dari ketua Koperasi Peternak Galur Murni (KPGM), peternak yang tergabung dalam KPGM, hingga dari pihak SKPD yang dalam hal ini Dinas Ketahanan Pangan dan Peternakan Kabupaten Jember. Maka diperoleh beberapa permasalah yang berkaitan dengan kualitas susu segar yang dihasilkan oleh sapi perah dari para peternak yang tergabung di dalam Koperasi Peternak Galur Murni (KPGM) tersebut. Adapun permasalahan tersebut disusun berdasarkan cause and effect diagram yang terdiri dari aspek man (manusia/tenaga kerja), material (bahan baku), method (metode), machine (alat/mesin), dan environment (lingkungan) seperti yang tampak pada gambar berikut ini.

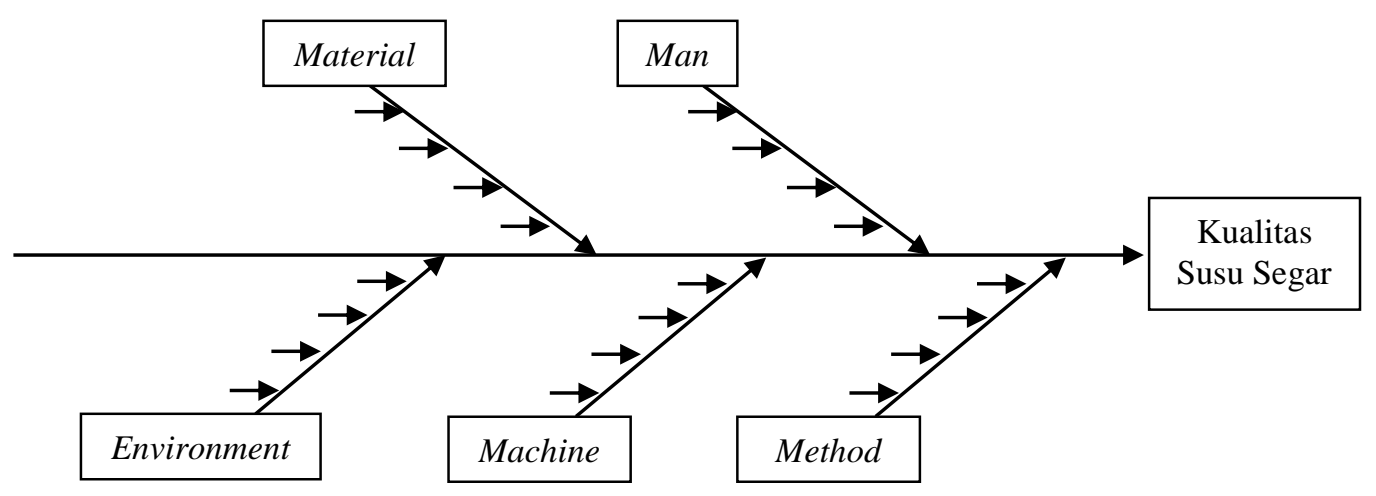

Gambar 2. Cause and Effect Diagram pada Manajemen Kualitas Susu Segar

Permasalahan atau penyebab yang sering terjadi dan berkaitan dengan manajemen kualitas susu segar tersebut diamati dari beberapa faktor seperti tampak pada Tabel 5.1 berikut ini.

Tabel 1. Permasalahan Sebab Akibat dalam Manajemen Kualitas Susu Segar di Koperasi Peternak Galur Murni (KPGM)

\begin{tabular}{ll}
\hline \multicolumn{1}{c}{ Faktor yang Diamati } & \multicolumn{1}{c}{ Masalah yang Terjadi } \\
\hline Man & a. Kedisiplinan Peternak \\
& b. Pengawasan Peternak \\
& a. Sapi Perah yang Kurang Sehat \\
Method & b. Kualitas Pakan \\
& a. Sistem Pemerahan yang Tidak Terpisah dengan \\
& Kandang \\
& b. Beberapa Peternak Melakukan Pemerahan secara \\
Machine & a. Peralatan (Konvensional) \\
& b. Peralatan yang Digunakan Peternak Masih Dikatakan \\
Environment & a. Kederhana \\
& b. Cuaca dan Suhu
\end{tabular}

Sumber: Data Primer

222 | Analisis Sebab Akibat Pada Pengelolaan Kualitas Susu Segar Di Kabupaten Jember, Jawa Timur (Studi Kasus pada Produksi Susu Segar di KPGM Kabupaten Jember) 
Berdasarkan tabel diatas dapat diketahui bahwa faktor-faktor yang menyebabkan susu segar yang dihasilkan KPGM terkadang kurang dari standard yang ditetapkan dikarenakan dari berbagai segi antara lain, man (manusia/tenaga kerja), material (bahan baku), method (metode), machine (alat/mesin), dan environment (lingkungan).

1. Man (Manusia atau tenaga kerja)

a. Kedisiplinan Pekerja

b. Pengawasan Pekerja

2. Material (Bahan Baku)

a. Sapi Perah yang Kurang Sehat

b. Kualitas Pakan

3. Methode (Metode)

a. Sistem Pemerahan yang Tidak Terpisah dengan Kandang

b. Beberapa Peternak Melakukan Pemerahan secara Manual (Konvensional)

4. Machine (Mesin)

a. Peralatan Pemerah yang Kurang Bersih

b. Peralatan yang Digunakan Peternak Masih Dikatakan Sederhana

5. Environment (Lingkungan)

a. Ketersediaan Air

b. Cuaca dan Suhu

Setelah mengetahui faktor penyebab dari permasalahan kualitas susu segar yang terjadi di KPGM, maka langkah selanjutnya yaitu menentukan penyebab-penyebab yang potensial dari permasalahan, dan menentukan penyebab yang paling dominan dari masing-masing permasalahan tersebut. Berdasarkan hasil indepth interview dengan responden expert, maka diperoleh penyebab yang paling dominan dari permasalahan tersebut. Adapun faktor penyebab dominannya terdiri dari lemahnya pengawasan peternak, rentannya penyakit pada sapi perah, sistem pemerahan yang tidak terpisah dengan kandang, peralatan yang digunakan masih sederhana, dan ketersediaan air.

Setelah diketahui faktor penyebab yang paling dominan terhadap permasalahan, langkah selanjutnya yaitu menentukan rencana penanggulangan untuk menyelesaikan permasalahan tersebut. Adapun rencana penanggulangan terhadap permasalahan tentang manajemen kuallitas di KPGM dapat dilihat pada Tabel 2.

223 | Analisis Sebab Akibat Pada Pengelolaan Kualitas Susu Segar Di Kabupaten Jember, Jawa Timur (Studi Kasus pada Produksi Susu Segar di KPGM Kabupaten Jember) 
Tabel 2. Rencana Penanggulangan Permasalahan Manajemen Kualitas Susu Segar di Koperasi Peternak Galur Murni (KPGM)

\begin{tabular}{|c|c|c|}
\hline Faktor yang Diamati & Permasalahan yang Terjadi & Rencana Penanggulangan \\
\hline Man & Pengawasan peternak & $\begin{array}{l}\text { Kontrol kualitas di setiap } \\
\text { segmen }\end{array}$ \\
\hline Material & Kualitas pakan & $\begin{array}{l}\text { Perbaikan kualitas pakan } \\
\text { (hijauan) }\end{array}$ \\
\hline Methode & $\begin{array}{l}\text { Sistem pemerahan tidak } \\
\text { terpisah dengan kandang }\end{array}$ & Pembangunan Infrastruktur \\
\hline Machine & $\begin{array}{l}\text { Peralatan yang digunakan } \\
\text { peternak masih sederhana }\end{array}$ & $\begin{array}{l}\text { Penyuluhan dan Pengadaan } \\
\text { peralatan }\end{array}$ \\
\hline Environment & Ketersediaan air & $\begin{array}{l}\text { Pembuatan sumber mata air } \\
\text { artesis }\end{array}$ \\
\hline
\end{tabular}

Sumber: Data Primer

\section{KESIMPULAN}

Berdasarkan hasil pembahasan dalam penelitian maka dapat disimpulkan bahwa faktor penyebab dalam kualitas susu segar di KPGM yaitu berupa lemahnya pengawasan peternak, jumlah pakan hijauan, sistem pemerahan yang tidak terpisah dengan kandang (minimnya infrastruktur), peralatan yang digunakan masih sederhana, dan ketersediaan air. Rencana penanggulangan yang dapat dilakukan yaitu berupa control kualitas di setiap segmen, perbaikan pengelolaan pakan hijauan, pembangunan infrastruktur, penyuluhan dan pengadaan peralatan, dan pembuatan sumber mata air artesis.

\section{DAFTAR PUSTAKA}

Gaspersz, Vincent. 2008. Total Quality Management (TQM). Jakarta: PT Gramedia

Irawati, Dany Alifah dkk. 2017. Strategi Pengembangan Koperasi Peternak Galur Murni di Kabupaten Jember. Jurnal Aplikasi Bisnis dan Manajemen Vol.3, No.1, Januari 2017

Silalahi, Ulber.2010. Metode Penelitian Sosial. PT.Refika Aditama: Bandung

224 | Analisis Sebab Akibat Pada Pengelolaan Kualitas Susu Segar Di Kabupaten Jember, Jawa Timur (Studi Kasus pada Produksi Susu Segar di KPGM Kabupaten Jember) 